\title{
Large-scale treeline changes recorded in Siberia
}

\author{
Jan Esper and Fritz H. Schweingruber \\ Swiss Federal Research Institute WSL, Birmensdorf, Switzerland \\ Received 27 November 2003; revised 30 January 2004; accepted 10 February 2004; published 16 March 2004.
}

[1] Analysis of a multi-species network of western Siberian ecotone sites revealed pulses of tree invasion into genuine treeless tundra environments in the 1940s and 1950s and after the early 1970s. In addition, increases in radial stem growth synchronous to the late 20th century treeline change are observed. Both treeline changes and growth increases correspond with decadalscale periods of temperature that are warmer than in any other period since observations started, suggesting - even if indirect - the sensitivity of large-scale treeline changes to this climatic forcing. The mid 20th century recruitment period reported here for the western Siberian network is compared with local findings from Europe and North America suggesting a circumpolar trend perhaps related to climate warming patterns. For western Siberia, the presence of relict stumps, nevertheless, indicates that this present colonization is reoccupying sites that had tree cover earlier in the last millennium. INDEX TERMS: 1620 Global Change: Climate dynamics (3309); 1630 Global Change: Impact phenomena; 9315 Information Related to Geographic Region: Arctic region. Citation: Esper, J., and F. H. Schweingruber (2004), Large-scale treeline changes recorded in Siberia, Geophys. Res. Lett., 31, L06202, doi:10.1029/2003GL019178.

\section{Introduction}

[2] 20th century warming patterns have been demonstrated to affect the photosynthesis [Lucht et al., 2002] and growth rate [Esper et al., 2002] of forest ecosystems. Instrumental temperature records show and models predict some of the greatest warming in the Northern Hemisphere land areas covered by the treeline tundra-taiga ecotone [Hansen et al., 1999; Jones et al., 1999]. This ecotone is an ecological boundary that evolves from the interaction between environmental conditions and vegetation itself [Arno and Hammerly, 1984]. At more local scales tree recruitment is related to some combination of temperature variations, micro-site conditions, insect outbreaks, wintertime snow and wind conditions and grazing pressure [Holtmeier, 2000; Payette, 1974; Payette and Filion, 1985; Stöcklin and Körner, 1999]. Nevertheless, it has been argued that growing season temperature alone determines global treeline limits [Brockmann-Jerosch, 1919; Körner, 1998].

[3] Focusing on the temporal dynamics of subarctic treelines, several dendroecological studies, including comparisons of repeated photographs and studies of tree growth forms, have revealed treeline positional and structural changes during the 20th century in Scandinavia [Aas,
1969; Hofgaard et al., 1991; Hustich, 1958; Kullmann, 1986], the Polar Urals [Gorchakovsky and Shiyatov, 1978; Shiyatov, 1992], Quebec [Lavoie and Payette, 1994; Payette et al., 1985], and in the Canadian Rocky Mountains [Luckman and Kavanagh, 1998], for example. However, the observations from these Northern Hemisphere subarctic treeline sites vary: in some cases, the local treelines have advanced, whereas in other cases they have remained static.

[4] In this study we aim to overcome some of the limitations typical to local approaches and analyze treeline dynamics over western Siberia during the 20th century by comparing nine undisturbed polar sites located between $59^{\circ}-106^{\circ} \mathrm{E}(\sim 1900 \mathrm{~km})$ and $61^{\circ}-72^{\circ} \mathrm{N}(\sim 1100 \mathrm{~km}$, Figure 1). However, this large-scale approach precludes detailed ecological and environmental justification of treeline dynamics as, for example, long-term local forcing data are broadly lacking. Nevertheless, by merging the information from nine sites, larger-scale patterns of treeline changes are demonstrated, and related to decadal-scale temperature variations. Current treeline positions are also related to former treeline extension by documenting in-situ remnants of relict stumps and logs.

\section{Treeline Sampling Strategy}

[5] To quantify treeline dynamics we used the following sample site properties:

[6] (i) The germination ages of 276 trees, dated by counting the annual stem growth rings,

[7] (ii) 147 abrupt growth releases from the same trees, defined as a doubling (or greater) in the ring widths, by a step function, relative to the earlier sequence (for clarification see Figure 2).

[8] To obtain accurate germination dates, we took disk samples at the level of the soil litter layer from trees with diameters less than $\sim 10 \mathrm{~cm}$. From the few remaining larger trees, $5 \mathrm{~mm}$ increment cores were taken above ground at an angle so as to hit the sprout area or root collar. Disks and cores were polished [Stokes and Smiley, 1968] and micro cuts prepared, when rings were exceptionally narrow [Schweingruber, 1978]. These procedures, especially sampling at the level of the soil litter layer, minimize possible dating errors for determining the exact year of tree germination. We estimate any error to be $\leq 3$ years.

[9] Due to the large area considered in this study and the differing ecological situations found in the field (Table 1) a stringent ecological classification of all sites is impractical. We therefore classify the sites more generally into "Forest Boundaries", defined as the transitional zone from a closed forest to the open edges of the forest, and "Ecotones", defined as the transitional zone between the forest boundary and tundra environments, i.e., they represent saplings that advanced into the genuine treeless tundra in the 20th 


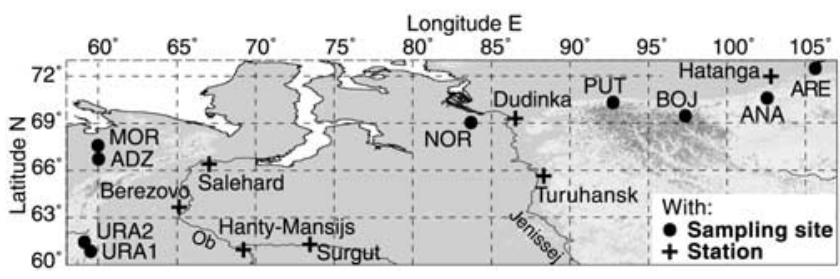

Figure 1. Map showing treeline sampling sites and climate stations. URA1 $=$ N-Ural 1, URA2 $=$ N-Ural 2, both Pinus; $\mathrm{MOR}=$ More $\mathrm{Ju}, \mathrm{ADZ}=$ Adzva, both Picea; NOR = $\mathrm{W}$ Norilsk, $\mathrm{PUT}=$ Putorana, $\mathrm{BOJ}=$ Bojarska, ANA $=$ Anabarskoe, $\mathrm{ARE}=$ Aremas, all Larix.

century. The latter are additionally sub-classified as "Elevation Ecotones", when upslope of the upper forest boundary, and as "Wind Ecotones" for wind-stressed sites in the area of the northern forest boundary. Trees sampled are split into upright saplings $<0.5 \mathrm{~m}$ and $>0.5 \mathrm{~m}$, and krummholz growth forms [Kullmann, 1981; Payette et al., 1985].

[10] The sampled material represents a compilation of tree species, Pinus sibirica (Siberian pine) from the northern Urals, Picea obovata (spruce) from west of the Urals, Larix sibirica and Larix cajanderi (larch) from east of the Urals (Table 1). The sites MOR, ADZ, NOR are located in forest enclaves within the subarctic tundra, PUT and BOJ are in the Putorana Mountains, ARE is on the Taimyr Peninsula, ANA on the Anabarskoe Plateau, and URA-1 and URA-2 are in the northern Urals. All sites lie above permafrost, on gentle slopes, summits or plateaus, and are without impact from humans, fire, changing water tables, solifluction, and away from reindeer paths.

[11] The entire region is characterized by continental, dry climates with long and cold winters. There is, however, a longitudinal and a latitudinal structure across the network. Along the Ural Mountains, for example, the upper treeline declines from $1000 \mathrm{~m}$ a.s.1. at $61.0^{\circ} \mathrm{N}$, to only $400 \mathrm{~m}$ a.s.l. at $66.5^{\circ} \mathrm{N}$. And the average annual numbers of days with mean daily temperatures $>10^{\circ} \mathrm{C}$ is 60 at Salechard $\left(66.5^{\circ} \mathrm{N} /\right.$ $66.7^{\circ} \mathrm{E}, 24 \mathrm{~m}$ a.s.l.) vs. 26 at Hatanga $\left(72.0^{\circ} \mathrm{N} / 102.5^{\circ} \mathrm{E}\right.$, $50 \mathrm{~m}$ a.s.1.) about $50 \mathrm{~km}$ and $70 \mathrm{~km}$ south of the northern forest boundary, respectively [Walther and Lieth, 19601967] (see Figure 1). Within the network the period of cambial activity is short. We found that pine in the northern Urals and spruce west of the Urals had started latewood production by June 16, 2001, and ring growth in larch from the Putorana Mountains was already completed by August 01, 2001.

\section{Treeline Changes}

[12] Pulses of treeline changes are recorded in the mid and late 20th century (Figure 3). Even though these pulses seem to be synchronous between several of the sampling sites studied, significant regional-scale differences can be seen: The first recruitment wave $1940-1960$ is found in seven of the nine sites (not in URA-2 and ARE). Trees that germinated during this period have upright growth forms except for the wind ecotones where they persist in microsite depressions as krummholz (Figure 3c). A second period of enhanced recruitment started around 1972 east of the Urals (four sites) lasting into the 1980s (Figure 3a). Around
1983 , in the northern Urals, upright trees $<0.5 \mathrm{~m}$ started to establish and grow further upslope. Contemporaneously, rapid increases of radial tree growth over the entire transect are observed (Figure 3, crosses).

[13] Only a few older krummholz trees that germinated in the late 18th and 19th centuries were found within the network (Figure 3c). In general, at sites where trees have migrated into the treeless subarctic tundra they are all less than 75 years old independently of growth from.

[14] The majority of sampled trees grew extremely slowly after germination (Figure 2). A random sample of 44 differently aged trees indicates that such initial periods of restricted juvenile growth last between 3 and 22 years with mean (and min.-max.) growth rates of only $0.10(0.04-0.15), 0.09$ (0.06-0.16), and $0.07(0.03-0.11) \mathrm{mm} /$ year at URA-1, PUT, and ANA, respectively. At URA-1 79\%, and at PUT and ANA $100 \%$ of samples showed this period of suppressed growth.

[15] No mortality data can be provided from these periods to document the loss of saplings. If saplings survive the initial restricted growth period they may reach heights of $4 \mathrm{~m}$ after about 50 years in favorable microclimatic situations (e.g., NOR), or remain as krummholz in wind ecotones (e.g., ADZ).

\section{Correspondence With Climate}

[16] Over this large area it is not possible to relate the observed treeline changes to detailed environmental forcing data at the local scale. First, there are few such data available from the study regions in western Siberia. Secondly, data from an individual site might only show a single recruitment or release period. Further, relating such data (i.e., the counting/dating of plants and growth events) with higher-order temperature data, for example, does not allow simple techniques to demonstrate the statistical significance of relationships, let alone to prove causality. With these limitations in mind, here we merge the data from the nine sampling sites to provide an overview of treeline changes, and graphically compare these findings with large-scale temperature patterns recorded at seven western Siberian meteorological stations (Figure 4).

[17] The recorded 20th century treeline changes correspond with annual decadal-scale temperature variations. This correspondence can be visually verified by comparing the germination dates of surviving saplings and abrupt

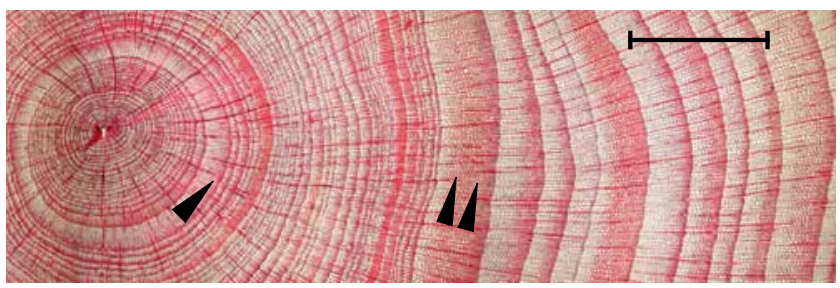

Figure 2. Cross section of a 64-year old Larix sibirica from the Anabarskoe plateau. The initial period of restricted growth, with a mean ring width of $0.035 \mathrm{~mm} / \mathrm{year}$, is interrupted by a wide ring (arrow). In 1989 (two arrows) an abrupt growth release, defined as a doubling (or greater) in ring widths over more than three years, occurred and ring widths increased to $0.2 \mathrm{~mm} /$ year. Scale bar is $1 \mathrm{~mm}$. 
Table 1. Sampling Site, Forest Type and Tree Type Characteristics ${ }^{\mathrm{a}}$

\begin{tabular}{|c|c|c|c|c|c|c|c|}
\hline Site & Species & Lat./Lon. & Elevation & Exp./Inc. & Forest Type & Tree Type & Samples \\
\hline N-Ural 1 & Pinus sibirica & $61^{\circ} 26^{\prime} \mathrm{N} / 59^{\circ} 43^{\prime} \mathrm{E}$ & $920-950 \mathrm{~m}$ & $-10^{\circ}$ & Wind ecotone & Saplings and Krummholz & 84 \\
\hline N-Ural 2 & Pinus sibirica & $61^{\circ} 49^{\prime} \mathrm{N} / 59^{\circ} 22^{\prime} \mathrm{E}$ & $730-800 \mathrm{~m}$ & $\mathrm{~S} / 10^{\circ}$ & Wind ecotone & Saplings & 23 \\
\hline More $\mathrm{Ju}$ & Picea obovata & $67^{\circ} 49^{\prime} \mathrm{N} / 60^{\circ} 01^{\prime} \mathrm{E}$ & $25-50 \mathrm{~m}$ & $\mathrm{~S} / 5^{\circ}$ & Forest boundary & Krummholz & 36 \\
\hline Adzva & Picea obovata & $67^{\circ} 08^{\prime} \mathrm{N} / 60^{\circ} 00^{\prime} \mathrm{E}$ & $60-90 \mathrm{~m}$ & $\mathrm{~S} / 15^{\circ}$ & Wind ecot., Forest bound. & Krummholz and Trees & 31 \\
\hline W Norilsk & Larix s & $69^{\circ} 01^{\prime} \mathrm{N}$ & $30 \mathrm{~m}$ & $-10^{\circ}$ & Forest bound. & Saplings and Trees & 21 \\
\hline Putorana & Larix species & $70^{\circ} 31^{\prime} \mathrm{N} / 92^{\circ} 57^{\prime} \mathrm{E}$ & $350 \mathrm{~m}$ & $\mathrm{~S} / 8^{\circ}$ & Elevation ecotone & Saplings and Krummholz & 17 \\
\hline Bojarska & Larix species & $69^{\circ} 57^{\prime} \mathrm{N} / 97^{\circ} 37^{\prime} \mathrm{E}$ & $590 \mathrm{~m}$ & $\mathrm{~S} / 2^{\circ}$ & Elevation ecotone & Saplings, Krummholz, Trees & 38 \\
\hline Anabarskoe & Larix species & $70^{\circ} 52^{\prime} \mathrm{N} / 102^{\circ} 53^{\prime} \mathrm{E}$ & $220 \mathrm{~m}$ & $\mathrm{~N} / 3^{\circ}$ & Elevation ecotone & Saplings and Krummholz & 20 \\
\hline Aremas & Larix species & $72^{\circ} 23^{\prime} \mathrm{N} / 105^{\circ} 52^{\prime} \mathrm{E}$ & $30 \mathrm{~m}$ & $\mathrm{~N} / 5^{\circ}$ & Elevation ecotone & Saplings & 6 \\
\hline
\end{tabular}

${ }^{\mathrm{a}} \mathrm{Exp} . /$ Inc. indicate exposition and inclination of sites. Some of the variance in the numbers of samples is related to logistical problems and field accessibility.

radial growth releases with mean annual temperature patterns (Figure 4). The germination and growth releases in the $1940 \mathrm{~s}-1950 \mathrm{~s}$ and after the early 1970 s correspond with decades of annual temperatures that are warmer than in any other period since observations started. The significance of temperature-forced treeline dynamics in western Siberia is additionally supported by the highly synchronous variations of temperature recorded at the seven meteorological stations (Figure 4, thin lines).

[18] For western Siberia, the correspondence with growing season (JJA) temperature variation is lower (Figure 4 (top)) than with annual temperature variation, suggesting that summer conditions alone would not as well explain the observed germination and growth releases. JJA temperatures show a delayed warming peak during the middle of the 20th century in the 1950s. Additionally, a warming trend in recent decades, as recorded in annual temperatures, is broadly missing. This well-documented [Hansen et al., 1999; Jones et al., 1999], significant trend in Siberia is predominantly driven by winter temperatures.

[19] The lack of germination events prior to the mid 20th century indicates this is an exceptional advance, the relict stumps and logs found at all sites, except URA-2, MOR and ADZ (Figure 3), show that this advance is part of a longterm reforestation process of tundra environments. While the decomposition rate of Pinus sibirica and Picea obovata remnants in the cold and dry Siberian climate is unknown, stumps and logs of Larix sibirica can be preserved for hundreds of years [Shiyatov, 1992]. Above the treeline in the Polar Urals such relict material from large, upright trees were sampled and dated, confirming the existence, around AD 1000, of a forest treeline $30 \mathrm{~m}$ above the late 20th century limit [Shiyatov, 2003]. This previous forest limit receded around 1350 , perhaps caused by a general cooling trend [Briffa, 2000; Esper et al., 2002].

\section{Discussion}

[20] A mid 20th century recruitment period, synchronous with the advance shown from the western Siberian network, is reported from central Sweden (1946-55) [Kullmann, 1981], northern Finland (1945-47) [Kallio, 1975], northern Quebec (1938-63) [Morin and Payette, 1984], and the Polar Urals (1940-55) [Shiyatov, 1992]. Together with the current results these findings from Europe and North America support a circumpolar trend, likely related to a global climate, warming pattern [Hansen et al., 1999; Jones et al., 1999]. Except for eastern larch in northern Quebec, we are, however, not sure we can compare our results with others as we are not fully knowledgeable of the sampling strategy used in these previous studies. If the age determinations of these other studies did not include sampling above the root collar, differences between our timing and the timing proposed by others could be significant.

[21] In western Siberia, saplings germinated during the mid (and late) 20th century, survived the first two decades and developed after some 50 years forests with trees up to $4 \mathrm{~m}$ tall - at least in wind-protected sites. During the initial period of restricted growth exceptional winter frosts, together with little snow-cover-protection, may have stressed the saplings of all species. Also fungal diseases such as caused by Phacidium infestans have affected Pinus sibirica saplings (URA-1). In general, we assume that locally differing ice melting processes, at the level of the root

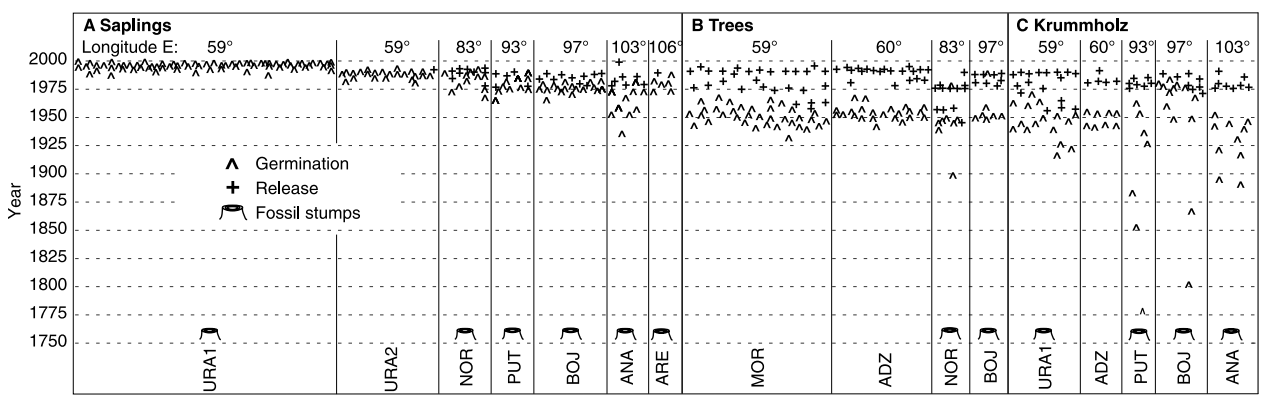

Figure 3. 276 germination dates and 147 growth release dates recorded in nine western Siberian sites. Tree growth forms and heights ordered: a, upright saplings $<0.5 \mathrm{~m}$, observed in seven sites; b, upright trees $>0.5 \mathrm{~m}$, observed in four sites; c, krummholz, observed in five sites. Fossil stumps and logs observed in URA-1, NOR, BOJ, PUT, ARE, ANA. For site locations and names see Figure 1. 


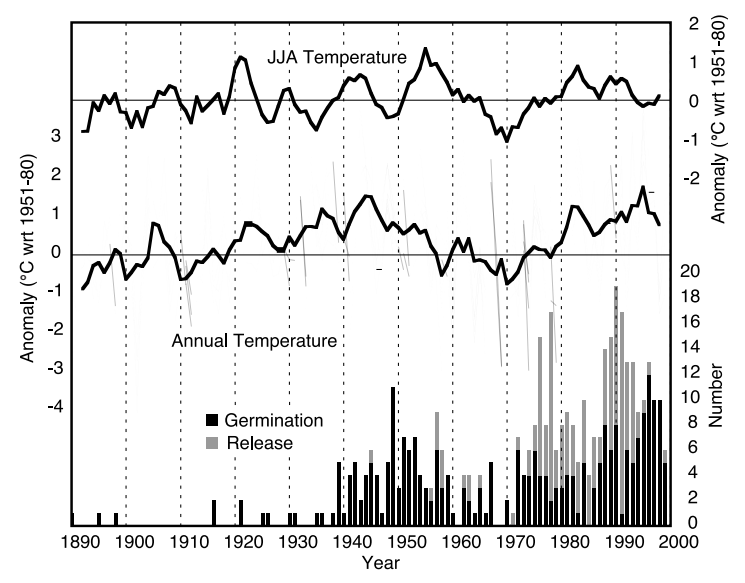

Figure 4. Mean JJA and annual temperature anomalies and the timing of tree germination and growth release. Thin lines indicate seven annual temperature records shown as anomalies from the 1951-1980 mean (climate stations and tree sites shown in Figure 1). Two stations (Berezovo, Turuhansk) have data back to 1881 . The Syktyvkar station, west of the study area $\left(61^{\circ} 70^{\prime} \mathrm{N}, 50^{\circ} 80^{\prime} \mathrm{E}\right)$, has data back to 1817. No Siberian station indicates temperatures as warm as in the 20th century. Bold lines are 5-year running means. The histogram indicates numbers of tree germination and growth release recorded in nine western Siberian treeline sampling sites.

horizon above the permafrost [Karlsson and Nordell, 1996] are crucial for the survival rate of the saplings. Some of these processes seem to be controlled by surface temperatures [Turner and Streule, 1983] and might explain the correspondence with decadal-frequency, annual temperature variations.

[22] However, we do not have a specific ecological explanation for the temperature-driven abrupt growth releases contemporaneously recorded in the western Siberian network. A clear relationship between growth release and enhanced vertical growth, i.e., the change from prostrate to erect growth, as reported from northern Quebec [Payette et al., 1985], cannot fully be confirmed for the western Siberian network, because these releases are present in both krummholz and upright (and skirted) [after Payette et al., 1985] trees.

[23] The increased correspondence with annual mean temperatures rather then with summer temperatures, particularly towards the most recent decade, indicates both winter and summer conditions might be relevant for the invasion of trees into genuine treeless tundra environments. However, the nature of our treeline data and the generally sparse data availability for Siberia do not allow robust statistical analyses to be performed. Thus, the current results should not be over interpreted in terms of the specific ecological processes driving treeline changes, but are noteworthy because they indicate for the first time some large-scale dynamics in an area from which a significant Northern Hemisphere warming trend is reported [Hansen et al., 1999; Jones et al., 1999].

[24] Acknowledgments. We thank S. Shiyatov, E. Vaganov, M. Haupt, L. Fellmann, L. Knuchel for logistic and fieldwork support, and C. Körner, S. Payette, D. Frank, P. Krusic, F. Hagedorn and two anonymous reviewers for helpful comments on the manuscript. Fieldwork supported by the Foundation Vontobel Bank, Winterthur Insurance, Leica/ Hasselblad, and Intersport. J.E. supported by the Swiss National Science Foundation; NCCR Climate.

\section{References}

Aas, B. (1969), Climatically raised birch lines in southeastern Norway 1918-1968, Nor. Geol. Tidsskr., 23, 119-130.

Arno, S. F., and R. P. Hammerly (1984), Timberlines: Mountain and Arctic Forest Frontiers, Mountaineers, Seattle.

Briffa, K. R. (2000), Annual climate variability in the Holocene: Interpreting the message of ancient trees, Quat. Sci. Rev., 19, 87-105.

Brockmann-Jerosch, H. (1919), Beiträge zur Geobotanischen Landesaufnahme, vol. 6, Baumgrenze und Klimacharakter, Rascher, Zürich.

Esper, J., E. R. Cook, and F. H. Schweingruber (2002), Low-frequency signals in long tree-ring chronologies for reconstructing past temperature variability, Science, 295, 2250-2253.

Gorchakovsky, P. L., and S. G. Shiyatov (1978), The upper forest limit in the mountains of the boreal zone of the USSR, Arct. Alp. Res., 10, $349-363$.

Hansen, J., R. Ruedy, J. Glascoe, and M. Sato (1999), GISS analysis of surface temperature change, J. Geophys. Res., 104, 30,99731,022 .

Hofgaard, A. L., L. Kullmann, and H. Alexandersson (1991), Response of old-growth montane Picea abies (L.) Karst. forest to climatic variability in northern Sweden, New Phytol., 119, 585-594.

Holtmeier, F. K. (2000), Arbeiten aus dem Institut für Landschaftsökologie, vol. 8, Die Höhengrenze der Gebirgswälder, Inst. for Landschaftsökologie, Münster, Germany.

Hustich, I. (1958), On the recent expansion of the Scots pine in northern Europe, Fennia, 82, 3-23.

Jones, P. D., M. New, D. E. Parker, S. Martin, and I. G. Rigor (1999), Surface air temperature and its variations over the last 150 years, Rev. Geophys., 37, 173-199.

Kallio, P. (1975), Reflections on the adaptations of organisms to the northern forest limit in Fennoscandia, paper presented at Circumpolar Conference on Northern Ecology, Natl. Res. Counc., Ottawa, Canada.

Karlsson, P. S., and K. O. Nordell (1996), Effects of soil temperature on the nitrogen economy and growth of mountain birch seedlings near its presumed low temperature distribution limit, Ecoscience, 3, 183189.

Körner, C. (1998), A re-assessment of high elevation treeline positions and their explanation, Oecologia, 115, 445-459.

Kullmann, L. (1981), Pattern and process of present tree-limits in the Tärna region, southern Swedish Lapland, Fennia, 169, 25-38.

Kullmann, L. (1986), Recent tree-limit history of Picea abies in the southern Swedish Scandes 1915-1975, Can. J. For. Res., 16, $761-$ 771 .

Lavoie, C., and S. Payette (1994), Recent fluctuations of the lichen-spruce forest limit in subarctic Quèbec, J. Ecol., 82, 725-734.

Lucht, W., I. C. Prentice, R. B. Myneni, S. Sitch, P. Friedlingstein, W. Cramer, P. Bousquet, W. Buermann, and B. Smith (2002), Climatic control of the high-latitude vegetation greening trend and Pinatubo effect, Science, 296, 1687-1689.

Luckman, B. H., and T. A. Kavanagh (1998), Documenting the effect of recent climate change at treeline in the Canadian Rockies, in The Impacts of Climate Variability on Forests, edited by M. Beniston and J. L. Innes, pp. 121-144, Springer-Verlag, New York.

Morin, A., and S. Payette (1984), Expansion récente du mélèze à la limite des forêts (Québec nordique), Can. J. Bot., 62, 1404-1408.

Payette, S. (1974), Classification écologique des formes de croissance de Picea glauca (Moench) Voss et de Picea mariana (Mill.) BSP. en milieux subarctiques et subalpins, Nat. Can., 101, 893-903.

Payette, S., and L. Filion (1985), White spruce expansion at the tree line and recent climatic change, Can. J. For. Res., 15, 241-251.

Payette, S., L. Filion, L. Gauthier, and Y. Boutin (1985), Secular climate change in old-growth tree-line vegetation of northern Québec, Nature, $315,135-138$.

Schweingruber, F. H. (1978), Mikroskopische Holzanatomie, Eidg. Anst. Forst. Versuchswes., Birmensdorf, Switzerland.

Shiyatov, S. G. (1992), The upper timberline dynamics during the last 1100 years in the Polar Ural mountains, in Oscillations of the Alpine and Polar Tree Limits in the Holocene, edited by B. Frenzel, pp. 195-203, Fischer, Stuttgart.

Shiyatov, S. G. (2003), Rates of in the upper treeline ecotone in the Polar Ural Mountains, Pages News1., 11, 8-10.

Stöcklin, J., and C. Körner (1999), Recruitment and mortality of Pinus sylvestris near the nordic treeline: The role of climatic change and herbivory, Ecol. Bull., 47, 168-177. 
Stokes, M. A., and T. L. Smiley (1968), An Introduction to Tree-Ring Dating, Univ. of Chicago Press, Chicago, Ill.

Turner, H., and A. Streule (1983), Wurzelwachstum und Sprossentwicklung junger Koniferen im Klimastress der alpinen Waldgrenze, in Wurzelökologie und Ihre Nutzanwendung, edited by W. Böhm, L. Kutschera, and E. Lichtenegger, pp. 617-635, Irding, Gumpenstein, Austria.
Walther, H., and H. Lieth (1960-1967), Klimadiagramm Weltatlas, Fischer, Jena.

J. Esper and F. H. Schweingruber, Swiss Federal Research Institute WSL, Zürcherstrasse 111, CH-8903 Birmensdorf, Switzerland. (esper@wsl.ch; schweingruber@wsl.ch) 